\title{
(C)
}

\section{Landslide Hazard Management and Control in India}

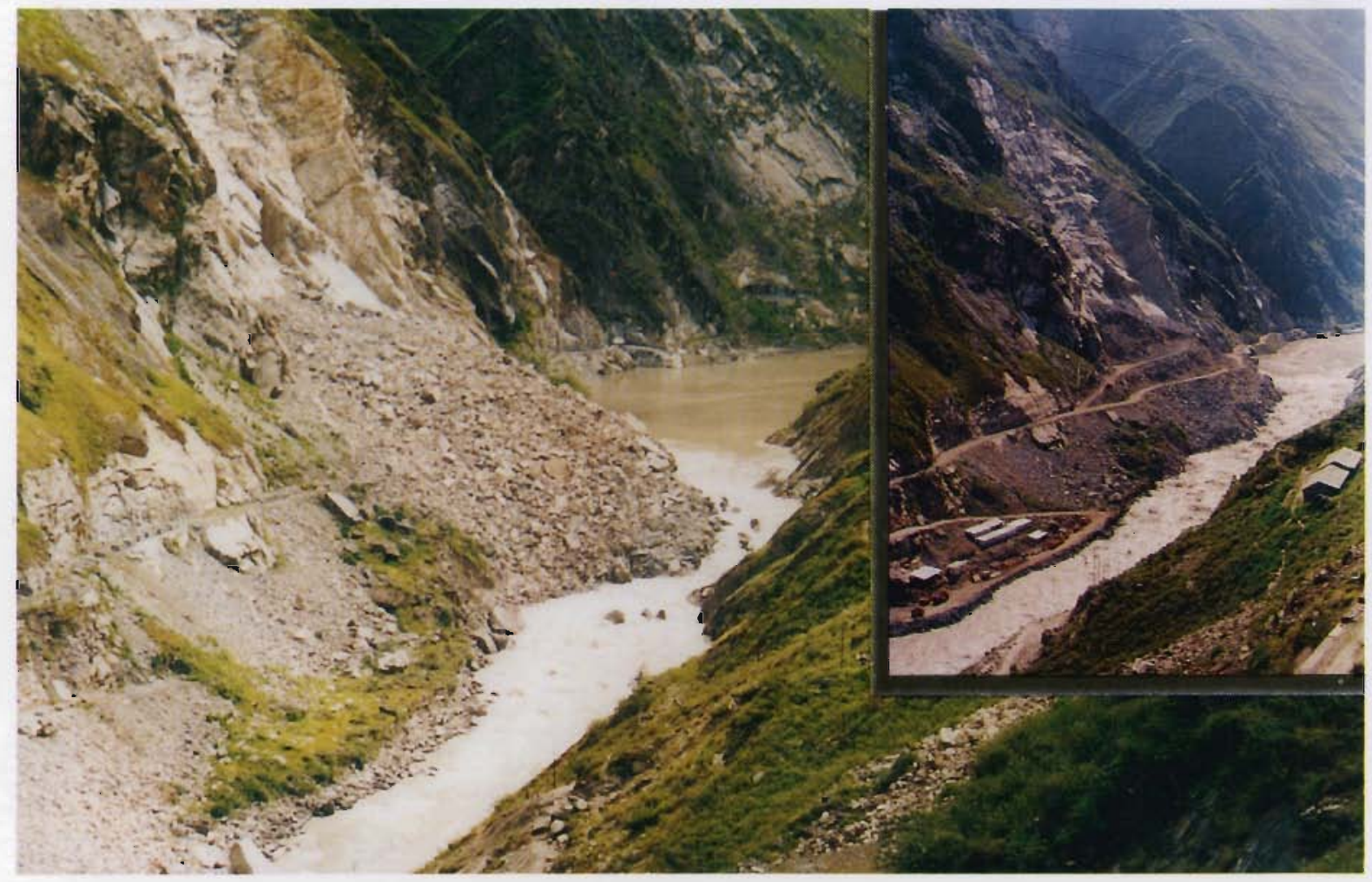

V.C. Thakur 
Copyright (C) 1996

Reprinted in 1997

International Centre for Integrated Mountain Development

All rights reserved

Cover Photograph: Two perspectives of the area near Nathpa village, NW

Himalayas - rockfall cum debris slide blocking the Sutlej

River (background) and translational debris slide on the same site, the imminent hazard to construction activities (inset)

Published by

International Centre for Integrated Mountain Development

G.P.O. Box 3226,

Kathmandu, Nepal

ISBN 92-9115-497-0

The views and interpretations in this paper are those of the author(s). They are not attributable to the International Centre for Integrated Mountain Development (ICIMOD) and do not imply the expression of any opinion concerning the legal status of any country, territory, city or area of its authorities, or concerning the delimitation of its frontiers or boundaries. 


\section{Landslide Hazard Management and Control in India}

\section{V.C. Thakur}

February 1996

International Centre for Integrated Mountain Development Kathmandu, Nepal 


\section{Preface}

The inherently unstable nature of mountain areas of the Hindu Kush-Himalayas is well recognised. The steep slopes, unstable geology, and intense monsoon rains combine to make the Hindu Kush-Himalayas one of the most hazard-prone areas in the world. Although natural hazards of varying intensity have occurred frequently in the past in Hindu Kush-Himalayan countries, more recently there has been an increase in human settlement of hazard-prone areas as a result of population pressure, as well as improvements in accessibility by road and the onset of other infrastructural developments. Consequently, natural and manmade disasters are on the increase and each event affects an even greater number of people than before. Floods and landslides during the monsoon season are the most common natural disasters affecting this region, often resulting in substantial economic and environmental losses and causing great suffering to many people.

Despite all this the present levels of understanding and systematic analysis of these disastrous events are very poor and data bases are non-existent. No monitoring activities are carried out even in cases where such monitoring can be of direct benefit to project-related management activities. Investments in developing practical guidelines for managing such events as well as in forecasting them have been inadequate.

Since its inception, ICIMOD has been promoting the development of a better understanding of natural hazards. Various activities have been undertaken so far. These include several training programmes dealing with mountain risk engineering, focussing on improving road construction along unstable mountain slopes, a review of landslide hazard management activities in China, and field assessment of landslides and flood events in south central Nepal following the extreme climatic events that took place in July 1993.

One of the goals set by ICIMOD in its Mountain Natural Resources' programme is to "Improve the conditions of mountain resources and environments by halting and eventually reversing their degradation." Programme activities envisaged to achieve the above goal are directed to:

- identification of measures to mitigate different types of natural hazards which result in the loss of natural resources;

- promotion of skills and methodologies for natural hazard assessment; and

- improvement of public awareness for better disaster preparedness in mountain areas.

ICIMOD's programme on "Landslide Hazard Management and Control" focusses on these concerns to help protect valuable natural resources from different types of natural hazards. This programme is based on activities already introduced at ICIMOD in 1994 with support from the Government of Japan.

This programme is concerned not only with examining the types and extent of landslide events but also with measures for their mitigation and control; and in addition the skills and methodologies needed for natural hazard assessment.

To improve the knowledge base on Landslide Hazard Management and Control, state-of-the-art reviews were commissioned in four countries of the Hindu Kush-Himalayan Region. These countries are China, India, Nepal, and Pakistan.

Suresh Raj Chalise of the Mountain Natural Resources' Division at ICIMOD coordinated the work carried out on these reviews and the current document entitled "Landslide Hazard Management and Control in India" was prepared by Dr. V.C. Thakur of the Wadia Institute of Himalayan Geology. Dr. Thakur has produced a comprehensive document on a topic that is crucial to the development of mountain areas and the well-being of mountain inhabitants. 


\section{Abstract}

'Landslide Management and Control in India' examines the problem of landslides in a mountain environment in which rising populations and an increase in infrastructural construction have led to augmentation in the probability of landslide occurrence. The various landslide triggers (rainfall erosion, deforestation, earthquakes, overburden of and construction of inappropriate infrastructure, geological causes, etc) and parameters of occurrence are discussed; a number of case histories are given in illustration. Methodologies for Landslide Hazard Zonation and map preparation are discussed, along with landslide hazard rating. Methods of landslide hazard mitigation are covered and an outline for a training programme is proposed as part of the paper's principal recommendations. 


\section{Contents}

\section{Introduction}

The Problem of Landslides

Environmental Impact of Landslides

on Urban Settlements

Landslides and Slope Stability in Nainital

Subsidence and Slips in Simla, H.P.

Mussoorie and Nainital

Impact on Farms and Agriculture and Infrastructure

Factors Controlling Landslides

Monsoon Rains and Landslides

Types of Damage and their Causes

Remedial Measures

Case History of the Naina Devi

Landslide in Himachal Pradesh

Deforestation and Landslides

Case History of Nashri Landslide

Earthquakes and Landslides

Geology and Landslides

Case History of the Minpui Slide

Reducing the Impact of Landslide

Disasters

Landslide Hazard Zonation

Case History of Aglar Catchment

Case History of Dehra Dun-Tehri

Case History of Doon Valley

Case History of Sutlej Valley

Methodology for Landslide

Hazard Zonation

Landslide Hazard Rating (LHR)

\section{Control Measures}

Drainage Measures

Surface Drainage

Catchwater Drains

Roadside Drains

Cross Drains

Subsurface Drainage

Horizontal Drains

Deep Trench Drains

Retaining Walls

Masonry Walls

Sausage Walls/Gabion Walls (SWG)

Pile Walls

Anchored Walls

Buttress Walls

Concrete Retaining Walls

Self-supporting Measures

Anchored Beam and Cable Lashing

Shotcreting

Soil Nailing

Geometry Alteration Measures
Surface Protection Measures

Planting

Reinforced Vegetation Using

Geogrids

Vegetative Turfing

Coir Netting

Soil Stabilisation

Grouting

Chemical Stabilisation

Case Histories of Landslide Control

Landslide ' $A$ '

Slide ' $B$ '

Landslide Dam and Flooding

Institutions Involved in Landslide

Research, Training, Warning,

Monitoring, and Management

Research and Development Efforts

Overall Conclusions and Recommend-

ations for a Practical Training

Programme

Overall Conclusions

Training Programme for Landslides Course Contents

Annexes

Bibliography

\section{List of Figures}

1: Geological cross-section across Golu Ka Khala Powerhouse area, Giri Hydel Project, H.P., showing geology and control measures (Krishnaswamy and Jain 1975)

2: Major instability zones in the Nainital town slide and the Ballia Valley (Valdiya 1987)

3: Geological setting of the Naina Devi landslide (upper figure) and remedial measures (lower figure) (Krishnaswamy 1980)

4: Geological framework of the Nashri landslide showing lithological and structural characteristics (Hukku and Narula 1975)

5: Control measures adopted for the Nashri landslide

6: Map showing October 1991 Uttarkashi earthquake-induced landslides based on pre- and post- earthquake IRS list II FFC imagery and aerial photographs (October 1991 Uttarkashi earthquake, Geological Survey of India 1992) 
7: Minpui landslide (B. Chatterjee)

8: Landslide hazard zonation map

9. Landslide Hazard Zonation map of Rishikesh-Shivpuri area in the Garhwal Himalayas (Choubey and Litoria 1990)

10. Landslide Hazard Zonation map along Sutlej Valley, Kinnaur District, Himachal Pradesh (Gupta et al. 1993)

11. Geological framework of the Khuni Nala . landslide and control measures undertaken, including alignment of the bridge along the Jammu-Kashmir highway (CRRI Report 1992)

12. Extensive control measures undertaken to mitigate landslide hazards in the Tista Valley, Sikkim (Bhandari and Gupta 1985)

12

A-1. Suggested nomenclature for landslides. Cross-hatching indicates undisturbed ground, stipping shows the extent of displaced material (13)

(IAEG Commission on Landslides 1990) 37

A-2. Section through typical slope movements (International Geotech. Soc. 1990)

\section{List of Tables}

1: Weighted Landslide Hazard Rating System in the Aglar Catchment (after Pachauri and Pant 1992)
2: Land Hazard Evaluation Factor (LHEF) Rating Scheme (after Anbalagan et al. 1993)

3: Landslide Hazard Rating System in the Upper Sutlej Valley of H.P. (after Gupta et al. 1993)

4: Assigned Rating of Various Thematic Maps (after DST Report 1993).

\section{List of Plates}

1: Sapni Slide: Combination of rotational debris slump and translational slide in the Quaternary overburden with graphitic horizons in the lower and middle valley slope of the Baspa River near the Baspa-Sutlej confluence, NW Himalayas 49

2: Rockfall : Wedge failure cum debris slide between Wangtu and Nathpa villages near Kandru Khad, NW Himalayas

3: Debris Slide: Looking from Wangtu bridge downstream. This slide is endangering the HPPWD Wangtu Rest House, NW Himalayas

4: Rockfall cum debris slide: near Nathpa village. This slide has blocked the Sutlej River creating a lake more than one kilometre long, NW Himalayas

5: Translational debris slide: near Nathpa village, NW Himalayas 